\title{
SOLVENT SEX
}

Pierre Klossowski: Living Currency

Edited by Vernon W. Cisney, Nicolae Morar, Daniel W. Smith.

New York: Bloomsbury, 2017. 112 pages.

ISBN 9781472508591.

Pierre Klossowski's last major theoretical text Living Currency (2017) saw it's first official' ${ }^{1}$ translation into English in May 2017, nearly fifty years after it was published in French. On the back of the book is a blurb quoting Foucault, in which he calls it 'the greatest book of our time'. This was almost certainly hyperbole; but whether or not his appraisal was correct (and I assure you it was not), it is a good book that advances a key to understanding Klossowski's literary and visual relationship to the exploited and monetized body, as this is the preoccupying theme throughout his fictional, non-fictional, and visual art. Joining the ranks of other books that have been published or republished recently (ranging from the more traditionally cold Marxism of The Productive Body (2014) by Guery and Deleule on the one hand, to Paul B. Preciado's deeply personal trans scripture Testo Junkie (2013) on the other), Living Currency is an artful entry into the body of works that attempt to understand how bodies are used, strictly speaking, for gain.

Klossowski has long been a figure that is hard to pin down, so if he were to produce a scholarly text on the merits of Marxism crossed with Sade's fiction, it would seem off brand. But this psychotic little book fits right in. The ideas contained therein are maximally exercised when confined to Klossowski's own creative output. They also provide a spooky footnote of reality to his drawings that did not previously exist in those dissociative second wave symbolist works. But Living Currency is more than just a key for a highly complex and original artist's train of thought. It is a paean to the recursive rules that he seems to have set upon his output. The topic is always similar: the thesis of celebrating bodily elegance, and the means by which it can be shown. What counts for Klossowski is how deeply, and for what price, one can feel another's body.

Those who are expecting the messianic dandies typically found in Klossowski's tasteful colored pencil drawings or his stylized novels and novellas will be quite surprised by the queasily academic 
arguments and declarations laced throughout Living Currency. Of course Klossowski has walked through this forest before with essays like "Decadence of the Nude" and Sade My Neighbor (1991), but never with such breadth and jargon as displayed in Living Currency. At times his writing feels alarmingly urgent, and at others it seems like he is almost lampooning his topic and his professional engagement with academic explications. It should be taken into consideration that the term academic is deceptive here as Klossowski is decidedly not an academic, nor does he seem to be interested in engaging with topics outside of his intense but small area of interest. But the erudite area that the term academic does denote is important for Klossowski since it is simultaneously his target and his crutch.

The eponymously titled essay that forms the focal point of this book is introduced to the reader as a brief hypothetical that is quickly exposed to be the harsh reality we live in by Klossowski's evaluation of the state of things. He asks the reader to imagine a world in which people are monetized and traded (similar to prostitution, but not quite), and then guess what? We already live in that world! But before jumping to delusions of Salo proportions he sets up his deduction as an intellectual dual between Sade and Fourier: his two chief inspirations. After all, he is one of the most serious acolytes of both Sade and Fourier in the twentieth century. As a brief reminder Sade is the infamous peddler of porn in the 18th century, and Fourier outlined and exacted utopian societies fairly soon after Sade's time. Society at the time viewed both men as, if not outright demented, then at least worthy of marginalizing for the greater good. Sade, Klossowski's principal obsession, even spent a stretch of time in prison for the novels that he published.

As a fanatical devotee of Sade, Klossowski takes it for granted that one finds the valorization of bodies in the equivalence of violation and worth. In Sade's work sex slaves are assigned worth based on what can be done to them (willingly or unwillingly), and how much of a violation it is to their dignity. Following this Klossowski suggests that we are engaged in the monetization of simulacra, or the unwilled mimetic fantasies each person has (phantasms in Klossowski's terminology). He thinks that the economy has transitioned from that of utensils to something more like an erotic version of an affect economy. Use value as a mark of distinction for intrinsic worth is no longer relevant for Klossowski the effete, as use value has reluctantly become useless, and simulacra have become useful. The notion of an economy of fabricated utensils being the primary means of transaction seems absurd to him because of the waning function of utensils in competition with simulacra. 
In describing his affective aspirations he appropriates Fourier's concept of the free play of emotions and says, 'We should note that the postulate that something can be 'free'...tends to disregard a primordial element of any voluptuous emotion, namely, its aggressive element, which presupposes and even demands resistance'. ${ }^{2}$ He is indicating what Fourier determined to be an essential part of societal relations (and thusly economic relations), namely playfulness, which inherently includes competitive power plays. People aggress upon other people as a way of exercising the free play of desire; the desire to own or be owned, punish or be punished, love or be loved, et al. Voluptuous emotion, by the way, refers to little more than the desire for erotic sensuality, or as Klossowski calls it, the state that 'precedes procreation', ${ }^{3}$ which is followed by his belief that in 'the economic order, the capacity to work is opposed to our affective life in general, and to voluptuous emotion in particular'. ${ }^{4}$

What he was getting at with this discussion about the free play of the emotions and victim values is something that may or may not be put more simply by saying that he is looking for a sort of morally permissible equivalent of prostitution (which is not to suggest that this author considers prostitution either moral or immoral, as that is a much larger discussion). He is trying to put forth an economy of bodies where the valued commodity is freely traded to the highest bidder, standard operating apart from the bodily aspect. The noble thing about it is that one has say in their own value based on a psychical demand for sexual satisfaction, as opposed to the prevalent system of labor exerted, physical or otherwise, equating to worth. The traditional dichotomy of supply and demand still applies, but it is a more decentralized evaluative system with options to have a say assigning oneself value.

Klossowski is greatly inspired by Sade's method of assessing his characters' values. Of the topic he says,

'For Sade's characters, the quality of being a single victim, on whom the torturer inflicts his tortures, sometimes takes precedence over the concept of the specific act. At other times, however, it is the same repeated act, indifferently inflicted on a larger quantity of victims, which affirms the quality of the act... Thus, Sade intuited, in the realm of emotion, what would ultimately become the principle of our modern economy in its industrial form: the principle of excessive production requiring excessive consumption. Produce destructible objects, and make consumers forget the very idea of a 'durable' object'. 5 
This sentiment proves a nihilistically bitter pill to swallow for two reasons. First, given the majority of his writing this book seems like a man of letters making his exit from the world of letters, which is in fact what he did around the time that it was originally published. He transitioned to being a visual artist almost exclusively, noting along the way that he had wanted a more corporeal language to adequately convey the contents of his mind, and that is exactly what he did by literally translating some of his most notable fictional characters into the exquisite drawings that dominated this next period. Now that would not seem so dire a situation if it were not for this second point: Klossowski writes in a nearly incoherently manner throughout the entirety of this inexplicably brief text (the actual essay Living Currency is only twenty two pages long). The text feels like writing's equivalent of speed-reading. It misses so much in between and gives nearly nothing that would not have been served better with more thoughtful indications of where his mind was. It is as feverish and phantasmagorical as its subject matter.

Flagrantly omitting much of the reasoning, or introducing concepts as already agreed upon, or glossing over entire schools of thought with little more than a sentence (sorry Keynes - Klossowski just made a mess of your entire economic thought and attributed it to you), is on the scale of (perhaps deliberate) mistakes that he squeezes into such a short text. It might be some version of academia jamming. Perhaps the book belongs in the parody subsection of the economics section at the library (population of one). Why did Foucault say that it was the greatest book of our time? Maybe he just wanted to make a close friend feel good. Maybe he thought it was a fresh take on bodily exploitation and evaluation through Klossowski's rhapsodic appraisal. Whatever the reason it was unequivocally a misnomer. But this is not a deleterious assessment; the book is thoroughly enjoyable for those who possess a keen interest in Klossowski's written and visual works. And it does seem to fit right into his oeuvre - it is not an aberration by any measure. On the contrary it is an excellent work to be perched at the threshold between his written and visual worlds.

Visual art was the climax of communication for Klossowski the writer. He was able to boil his libidinal texts into their most manifest appearance using the tools of mimetic picture making. The strengths of mimetic impulse in his economic and erotic writings are presented twofold in his colored pencil drawings. It is fitting then, that he spends a considerable amount of time in this, his final major text, presenting the reader with some very curious views 
of visual art, views that may seem to negotiate his way forward after such a bellicose essay. As Daniel W. Smith's introduction to Living Currency points out, Klossowski was an early translator of Benjamin's “Work of Art in the Mechanical Age”, and lifted the distinction of art as literally useless from his Marxist interpretation of artworks. The objects with use are naturally called utensils, and it is this dichotomy that Klossowski takes to task when discussing art.

Works of art, those 'rare and inert objects' 6 that form Klossowski's lingua franca, are no longer the only occupants of the useless-but-with-value category. The act of fabrication, for both utensils (useful objects) and pure simulacra (useless objects (artworks, strictly speaking)), has already captured the production of symbols. As a result 'only the simulacrum of art is supposed to make this inversion visible: since art is a simulation, its products are taken to be use-objects'. ${ }^{7}$ He goes on to say that the division is a result of simulacra being considered 'noble' and utensils being considered 'ignoble'. This is a mistaken position to take though, since:

'...if the simulacrum of art is a utensil of the passions, its simulation must likewise be an efficient operation. If it were merely a simulated simulacrum, it would be ineffective, since its effect is to be constantly reversible in its operations, and to have a use that is as malleable and variable as the life of the passions...In an art-product, an affect would find a way to express its phantasm. In a utensil, which refuses to express the phantasm, the affect would act under the cover of the usefulness of a thing that the affect has nothing to do with.' 8

Getting to the point of considering art to be just another commoditized symbol is a righteous gamble for someone who is jettisoning the act of writing almost indefinitely. And this is exactly where I believe the clever purpose of Living Currency is located: Klossowski wanted out of writing and into art making. He opened the spiritual door, walked in, and swallowed the key.

Klossowski's work as a visual artist was formally staid - there was not much happening in the actual content either. They are airy, refined drawings of figures in situations of erotic temptation (they alternate between very Catholic and very anti-), drawn from mythologies of his own making as well as canonized ones. But it is in relation to his research, his literary corpus, and his social circles that we can come to see the sophisticated drawings that occupied much of his output after Living Currency as the products of a nightmarish obsession with the repression of his countrymen. Klossowski was 
always a vanguard, even in his brief stint at seminary school; and he was one of the driving forces that pushed the envelope in France after the Second World War. Although Klossowski has traditionally been considered a writer first and an artist second, it is not hard to believe that he was an artist entirely, and that his texts were simply supplementary appendixes to his visual language.

Would Klossowski have found life in the current political climate to be more or less liberating than his own heyday? This question is important to ask for any historically relevant thinker, and especially for him, as he was looking for a way out of the endless circularity of talking, trying to develop a language that went above and beyond. He would have been vain in thinking that his work as an artist could shift the scales, but his purpose was solid and significant: draw attention to the economic inequalities of the world and take ownership of one's self. Klossowski might have been wrong about the letter, but he was right in spirit. He found a fixed expression in his colored pencil drawings to be sure. Other thinkers might likewise benefit from his example. At the very least it might help for the political pundits and pseudo-left of the world to hush up and sketch out something useful.

Nickolas Calabrese

NOTES

1 It was unofficially (and maybe not in the best tradition) translated twice before.

2 Klossowski, Living Currency, 53.

3 Ibid., 48.

Ibid., 58-60.

Ibid., 58.

Ibid., 74.

Ibid., 64.

8 Ibid. 